\title{
森林小流域で測定した比流出量の収劍性の検証
}

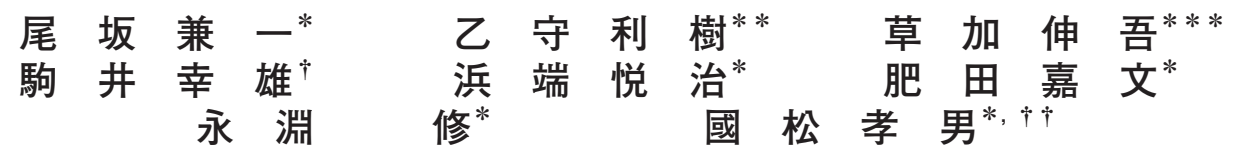

\section{Verification of Convergency of the Specific Discharges of Materials Measured at a Small Experimental Forested-Watershed}

\author{
Ken'ichi OSAKA*, Toshiki OTOMORI**, Shingo KUSAKA***, \\ Yukio KOMAI ${ }^{\dagger}$, Etsuji HAMABATA*, Yoshifumi HIDA*, \\ Osamu NAGAFUCHI* and Takao KUNIMATSU ${ }^{*}, \uparrow$
}

\footnotetext{
* Department of Ecosystem Studies, School of Environmental Science, University of Shiga Prefecture, 2500 Hassaka, Hikone, Shiga 5228533, Japan

* * Health \& Welfare Bureau of Sakai City, 3-1 Minami-Kawaramachi, Sakai-ku, Sakai, Osaka 590-0078, Japan

*** Lake Biwa Museum, 1091 Oroshimo, Kusatsu, Shiga 525-0001, Japan

$\dagger$ Department of Environmental Technology, Faculty of Technology, Osaka Institute of Technology, 5-16-1 Omiya, Asahi-ku, Osaka 5358585, Japan

$\uparrow \dagger$ Present address: College of Science and Engineering, Ritsumeikan University, 1-1-1 Noji-higashi, Kusatsu, Shiga 525-8577, Japan
}

\begin{abstract}
In the previous paper, the loading rates of $\mathrm{TN}$ and $\mathrm{TP}$ were measured in Aburahi-S Experimental Forested Watershed (AsEFW; $3.34 \mathrm{ha}$ ), and the specific loads $\left(\mathrm{L}_{\mathrm{S}} \mathrm{s}\right)$ were evaluated to be 9.95 and $0.168 \mathrm{~kg} \cdot \mathrm{ha}^{-1} \cdot \mathrm{y}^{-1}$, respectively. The $\mathrm{L}_{\mathrm{S}}$ values should be verified to converge within AsEFW in order to be appreciable as parameters characterizing AsEFW. However, it is difficult to install a sufficient number of weirs in such a small watershed to prove directly such convergence. In this paper, water samples of the baseflow were taken up monthly at twelve sites (R0-R7 and L1-L4) located upstream of the weir (R0) of AsEFW for one year. The average concentrations of the nutrients at R0 did not significantly differ $(\mathrm{p}<0.01)$ from those at R1-R4 within a distance of $130 \mathrm{~m}$. During two rainfall events $(58.5$ and 151 $\mathrm{mm}$ ), the concentrations were observed at R0, R1 and R3. The concentration levels and changing patterns were similar between R0 and these upstream sites. It was concluded, from these results, that the $\mathrm{L}_{\mathrm{S}}$ values converge within AsEFW. Since springs may affect significantly $\mathrm{L}_{\mathrm{S}}$ values, especially in small watersheds, their existence and effect should be checked. A small spring (L5) was found in AsEFW, and its influence on the $\mathrm{L}_{\mathrm{S}}$ values of the nutrients was confirmed to be negligible.
\end{abstract}

Key words: forest, nitrogen, phosphorus, specific load, convergence, small watershed

\section{1.はじめに}

一般に，河川の比流量と物質の比流出量（以下では一 括して比流出量という）および濃度は，時間的には非定 常 ${ }^{1 \sim 5)}$ で, 空間的には非均質 ${ }^{5 \sim 7)}$ な連続パラメーターで ある。人為污染源のない森林流域から流出する河川（以 下，渓流）でも同様で, 定点で測定した濃度と比流出量 は降雨の影響を受けて常に変動している。また，降雨は 流出する過程で流域に非均質に分布する気候・地質・地 形・土壤・植生など（以下，流域構成要素）による物理 化学的・生物化学的影響を受けるため, 渓流の濃度と比
流出量は谷頭から流下するに従って徐々に変化する。

森林の生物地球化学や物質収支に関する研究は, 目的 に合致した森林流域に実験小流域を設定して流出渓流の 末端に量水堰を設置し, 流量と濃度を測定して物質の流 出量を解析する小流域法で行われることが多い ${ }^{1 \sim 8)}$ 。小 流域法では流量は量水堰の水位記録から連続データが得 られるが, 全窒素（TN）, 全リン（TP）や主要イオンな どの物質の濃度は現状では連続デー夕を得ることは難し い。そこでこれまでの研究では,一定期間(例えば 1 年間) の物質の流出量は, 例えば 1 週間〜 1 力月に 1 回の濃度 と流量の調査データから調査時の流出量を計算し, 前後

* 滋賀県立大学環境科学部環境生態学科 $\bar{\top} 522-8533$ 滋賀県彦根市八坂町 2500

** 堺市健康福祉局健康部保健所 $\overline{\mathrm{T}} 590-0078$ 堺市堺区南瓦町 3-1

*** 滋賀県立琵琶湖博物館 $\overline{\mathrm{T}} 525-0001$ 滋賀県草津市下物町 1091

$\dagger$ 大阪工業大学工学部環境工学科 $\overline{\mathbf{T}} 535-8585$ 大阪市旭区大宮 5-16-1

$\dagger \dagger$ 現所属：立命館大学理工学部 ₹520-8577 滋賀県草津市野路東 1-1-1 
の $1 / 2$ 調查期間を代表させて積算するか, その期間濃度 は一定として流量のみ連続デー夕を使って流出量を計算 する方法がとられ, その精度の向上は濃度の調査頻度を 高めることによって達成できると考えられてきた。近年 になってようやく, 一々の降雨による濃度と流量の短期 の非定常性 ${ }^{6,7,9 \sim 11)}$ と水文条件の年変動に起因する長期 の非定常性 ${ }^{6.7)}$ を考慮して, 連続量としての流出量を推 定する方法について研究が進みつつある。

一方, 流域構成要素の非均質分布は小流域であっても 存在する。従って, 小流域内部でも渓流の濃度と比流出 量は，基本的には流下過程で連続的に変化しているはず である。ただし，小流域が拡大するにつれて主たる流域 構成要素の組成が平準化されて一定值に近づくような場 合は，濃度と比流出量も流下するに従って，一定值に収 斂し安定する可能性がある。言い替えれば, 実験小流域 で測定した濃度と比流出量は，小流域内部で収斂し安定 していなければ，その森林を代表するパラメーターとし ては評価できない。しかし，実際に実験小流域で測定し た濃度と比流出量が量水堰（流域末端）に至るまでの間 に一定值に収斂し安定していることを検証した研究は, これまでのところ見当たらない。

森林の水収支の研究では，これまで2つの方向で実験 流域の代表性が追求されてきた。1つは流域構成要素の 非均質性を考慮しなくもよいように, “均質な”山腹斜 面に $10 \sim 1,000 \mathrm{~m}^{2}$ 前後の小規模な方形区を設定したり， 1 〜数 $10 \mathrm{~m}^{2}$ のライシメーターを設置したりして，場を 極小化する方向である。しかし，例えば斜面の構造が異 なれば降雨の流出過程が異なり，それが流出のみならず 渓流水質にも反映することが示されている ${ }^{12)}$ 。また，斜 面実験で得られた流出現象は小流域での現象と必ずしも 一致せず，小流域の流出は多様な流出を示す斜面の集合 による平準化の結果であるとの指摘もある ${ }^{13) 。 ~}$

他は，逆に実験流域を拡大することによって非均質 性を平準化または収斂させる方向である ${ }^{14 \sim 16)}$ 。ところが, 日本のように流域構成要素が多様で, かつ人口密度が高 く実験流域を拡大すると人工要因(民家・事業所・田畑・ 池・取水など）の混在を避けられない地域では, 平準化 に必要な基準面積（representative elementary area）の妥当 性そのものの検証が難しい。水質化学の研究でも, 数 $\mathrm{km}^{2}$ を超える広流域に実験流域を設定して流出量を実測 し, これから流域内部に存在する特定污染源と森林以外 の非特定污染源から発生する污濁物質の発生量 (負荷量) を原単位法で計算して差し引くことによって，広域の森 林を代表する比流出量（原単位）を推定 ${ }^{3,17,18)}$ する試み はあり，河川法または広域河川法などと呼ばれてきた。 指摘するまでもなく, 広域河川法による森林の比流出量 の精度は, 定点で測定された流出量の精度のみならず, 各污染源を代表する原単位と発生源での処理率(浄化率) や河川での自然浄化率などの精度に左右される。従って, これらの原単位の精度と適用法が信頼できるレベルにあ れば，広域河川法は合理的な方法であるといえる。しか し, 原単位の精度はどれ 1 つ取っても, 広域河川法の合 理性を支持できるレベルにはなく3)，現状では屋上屋を 架すことにしかならない。

結局, 森林の物質収支または原単位の研究手法として は, 現状では広域河川法より小流域法が適していると考
えられるが，いずれにしても実験流域で測定した濃度と 比流出量が流域内部で一定值に収斂し安定していること を直接検証するためには, 実験流域の内部の渓流に量水 堰を 2 力所以上設置し, しかも非定常性を考慮して同時

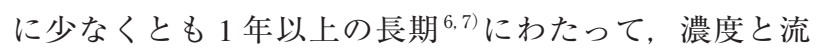
量を測定しなければならない。しかし, 実験流域の内部 に数多くの量水堰を設置することは, 多大の経費を要し, とくに小流域法の場合はわずか数 ha の実験小流域に多 数の量水堰を設置することはフィールドの擋乱・改変に 繋がり現実的ではない。

そこで本研究では，すでに報告した L (R）式法 ${ }^{6,7)}$ 適用して流出量を基底流出量と洪水流出量に分けて推定 した油日岳 $\mathrm{S}$ 森林実験小流域の TN と TP の比流出量 ${ }^{7)}$ を例にして, 実験流域内に 12 定点を設定し, 基底流出 量については下流域に設定した定点間の基底流濃度の有 意差検定によって, 洪水流出量についてはこれらの定点 間での洪水流出時の濃度レベルと変動の同調性の定性的 判定によって, 比流出量の収斂性 - 安定性を代替的に検 証した。

\section{2. 実験方法}

\section{1 実験流域の概要}

油日岳 $\mathrm{S}$ 森林実験小流域（以下, AsEFW）は, 前報 ${ }^{7}$ ) で詳述した滋賀県南東部鈴鹿山脈南端に位置する油日岳 （標高 $670 \mathrm{~m}$ ）の南斜面に位置する面積 3.34 ha（水平面積） の小集水域である（Fig. 1)。表層地質は粗粒花崗岩 ${ }^{19)}$ で ある。下流側 1.94 ha（58\%）はヒノキ Japanese cypress (Chamaecyparis obtusa Endl.)の造林地(以下, ヒノキ林)で, 上流側 1.40 ha は, コナラ (Quercus serrata Thunb.) を主 とする落葉広葉樹二次林 (以下, 落葉広葉樹林) である。 流出渓流は恒常水流で, 集水域末端に設置されている
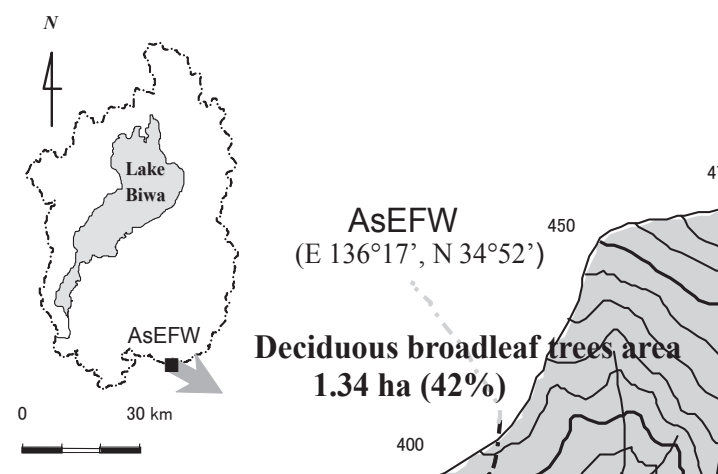

1.34 ha $(42 \%)$

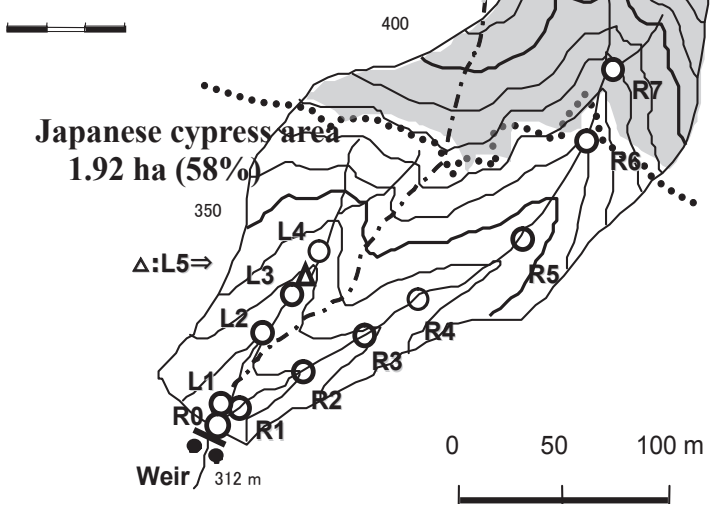

Fig. 1 Aburahi-S Experimental Watershed (AsEFW). The sampling sites of the stream waters in the sub-watershed $\mathrm{R}$ and L were marked by $\bigcirc$ and that of the small spring by $\triangle$. 
量水堰から約 $10 \mathrm{~m}$ 上流で分岐している。分岐点から上 流東側の内部流域の集水面積は 2.36 ha，西側は 0.98 ha で，それぞれ $\mathrm{R}$ 流域， L 流域と呼ぶ。流量は全幅殹の水 位記録から水位一流量式 ${ }^{20)}$ を用いて計算した。

\section{2 水質調査}

\section{2.1 調査定点}

量水堰を起点とする主河道（ $\mathrm{R}$ 流域）の斜面延長は $283 \mathrm{~m}$ である。堰槽に流入する直前の採水定点を R0 と して，上流に向かって $20 \sim 40 \mathrm{~m}$ 間隔で $\mathrm{R}$ 流域に 7 定 点（R1〜 R7），L 流域に 5 定点（L1〜 L5）を設定した。 ただし，L5 は L3 の上流約 $1 \mathrm{~m}$ の西側斜面の下部にある 直径約 $1 \mathrm{~cm}$ の小穴から流出する湧水である。

\section{2.2 基底流水質調査}

2004 年 1 月から 1 年間, 原則として月に 1 回, 前降 雨から 5 日以上経過し, 降雨の影響がないと思われる無 降雨日の流水を基底流と見なして, 各定点で採水し水質 を分析した。

\section{2.3 洪水流出水質精密調査}

$151 \mathrm{~mm}$ の降雨時（2002 年 7 月 9 〜 10 日）に R0, R3, L3 の 3 定点で, $58.5 \mathrm{~mm}$ の降雨時（2004 年 12 月 $4 \sim 5$ 日） には R0 〜 R7, L1 〜 L5 定点でほぼ同時に 1 〜数時間間 隔で採水して水質を分析した。

\section{3 水質分析}

水質は JIS 法 ${ }^{20)}$ および上水試験法 ${ }^{21)}$ に準拠して, 前報 6,7) と同様の方法で分析した。粒子性成分を含む窒素 $(\mathrm{N})$ とリン（P）は， ろ過前の検水の分析值をそれぞれ TN, TP 濃度, 孔径 $1 \mu \mathrm{m}$ のガラス䋊維滤紙でろ過した検水
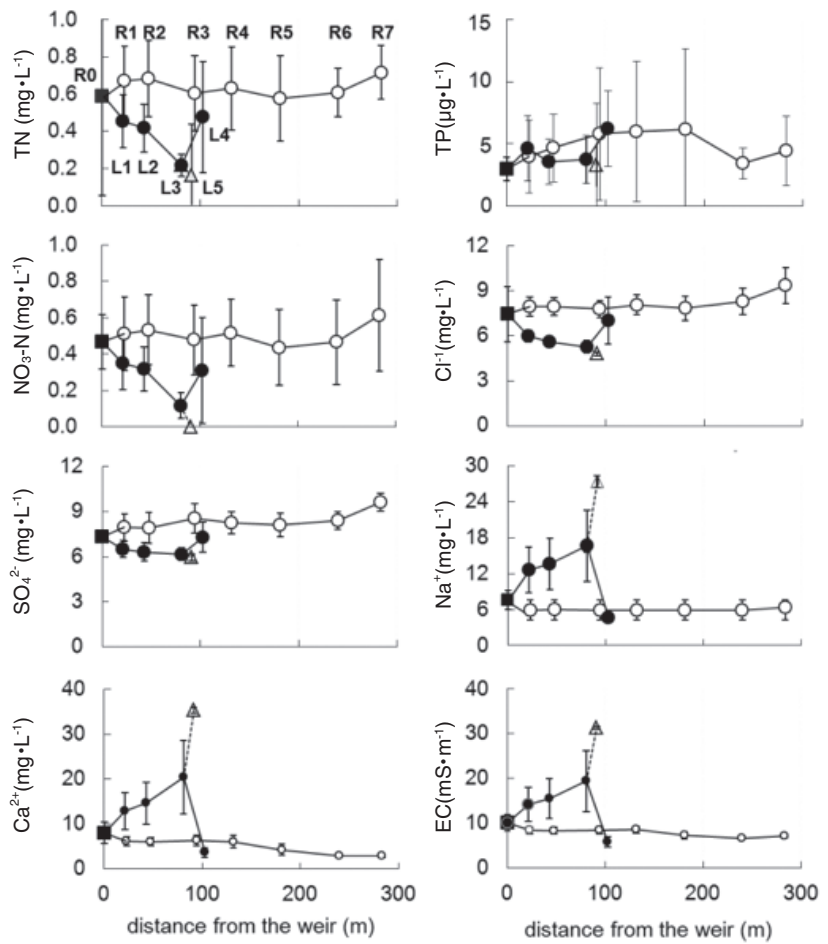

Fig. 2 Changes in the average water qualities of baseflows in Aburahi-S Experimental Forested Watershed. Water qualities were measured monthly from 2004.01-2004.12 on non-rainy day at 7 sites on the stream draining from subwatershed $\mathrm{R}(\bigcirc), 4$ sites on the stream ( $\bigcirc)$ and a small spring in sub-watershed L $(\triangle)$ in Fig. 1. Error bars showed standard deviations $(\mathrm{n}=12)$.
の分析值を溶存性全窒素 (DN)・全リン（DP）濃度とし， 両者の差をそれぞれの粒子性成分（PN, PP）の濃度と した。有機炭素（OC）は $58.5 \mathrm{~mm}$ の洪水流出水質精密 調査について溶存成分 (DOC) のみ測定した。DN と溶 存無機性窒素 $\left(\mathrm{DIN}=\right.$ アンモニア性窒素 $\left(\mathrm{NH}_{4}-\mathrm{N}\right)$ +硝 酸性窒素 $\left(\mathrm{NO}_{3}-\mathrm{N}\right)+$ 亜硝酸性窒素 $\left.\left(\mathrm{NO}_{2}-\mathrm{N}\right)\right)$ との差を 溶存有機性窒素 $(\mathrm{DON}), \mathrm{DP}$ とリン酸性リン $\left(\mathrm{PO}_{4}-\mathrm{P}\right)$ との差を溶存有機性リン（DOP）とした。

主要無機イオンはナトリウムイオン $\left(\mathrm{Na}^{+}\right)$, カリウム イオン $\left(\mathrm{K}^{+}\right)$, カルシウムイオン $\left(\mathrm{Ca}^{2+}\right)$, マグネシウム イオン $\left(\mathrm{Mg}^{2+}\right)$, 塩化物イオン $\left(\mathrm{Cl}^{-}\right)$, 硫酸イオン $\left(\mathrm{SO}_{4}{ }^{2-}\right)$ および重炭酸イオン $\left(\mathrm{HCO}_{3}^{-}\right)$を分析した。各定点の $\mathrm{NH}_{4}{ }^{+}$は低濃度で, フッ化物イオンやホウ酸イオンも問 題になる濃度ではなく, $\mathrm{pH}$ も中性付近であったので, $\mathrm{HCO}_{3}$ - はアルカリ度から計算した。その外に溶存ケイ酸 $\left(\mathrm{SiO}_{2}-\mathrm{Si}\right)$, 電気伝導率 $(\mathrm{EC})$, 水素イオン濃度 $(\mathrm{pH})$ を 分析した。

分析值の判定下限を $1.64 \sigma$, 検出下限を $3.28 \sigma$, 定量 下限を $10 \sigma$ と仮定すると, TN はそれぞれ $0.031 ， 0.061$, $0.190 \mathrm{mg} \cdot \mathrm{L}^{-1}$, TP $0.003,0.006,0.017 \mathrm{mg} \cdot \mathrm{L}^{-1}$ であった。 水質データの有意差は $\mathrm{F}$ 検定を行い, 分散をパラメト リックと仮定して $\mathrm{t}$ 検定を行った。

\section{3. 実験結果}

\section{1 基底流の水質の分布}

1 年間調査した基底流水質の算術平均值（ $\mathrm{n}=12 ）$ と 標準偏差 $( \pm \sigma)$ を量水堰 R0 からの斜距離に対してプ ロットした結果をFig. 2 に示し, Table 1 に主な定点の 数值を示した。AsEFWには2つの内部流域があるが, まず $\mathrm{R}$ 流域（R1～R7）について検討する。 $\mathrm{TN}$ の平均 濃度は最上流の定点 R7 から R6にかけてやや低下した が, それ以降は $\mathrm{R} 1$ まで $0.6 \mathrm{mg} \cdot \mathrm{L}^{-1}$ 前後で流下した。 $\mathrm{TN}$ の約 $80 \%$ を占める $\mathrm{NO}_{3}-\mathrm{N}$ もほほ同様の傾向を示した。 一方, TP の平均濃度は定量下限以下で, 検出下限付近

Table 1 Average concentrations of the base flow measured at the sites in AsEFW* $\left(\mathrm{mg} \cdot \mathrm{L}^{-1}\right)$

\begin{tabular}{|c|c|c|c|c|c|c|c|}
\hline \multirow{2}{*}{ items } & \multicolumn{7}{|c|}{ sites in AsEFW* } \\
\hline & R0 & $(\mathrm{SD} \%)$ & R1 & L1 & L4 & L5 & $(\mathrm{SD} \%)$ \\
\hline $\mathrm{EC}\left(\mathrm{mS} \cdot \mathrm{m}^{-1}\right)$ & 10.0 & (18) & 8.36 & 14.2 & 5.79 & 31.3 & (1) \\
\hline $\mathrm{pH}$ & 7.04 & (4) & 7.08 & 7.50 & 6.65 & 7.70 & (1) \\
\hline $\mathrm{NO}_{3}-\mathrm{N}$ & 0.469 & (37) & 0.511 & 0.353 & 0.309 & 0.000 & $(-)$ \\
\hline $\mathrm{NH}_{4}-\mathrm{N}$ & 0.006 & (109) & 0.003 & 0.009 & 0.020 & 0.037 & (63) \\
\hline $\mathrm{DN}$ & 0.555 & (8) & 0.622 & 0.442 & 0.432 & 0.039 & (80) \\
\hline $\mathrm{TN}$ & 0.589 & (11) & 0.670 & 0.455 & 0.478 & 0.161 & (173) \\
\hline $\mathrm{PO}_{4}-\mathrm{P}$ & 0.0013 & (29) & 0.0020 & 0.0018 & 0.0025 & 0.0015 & $(60)$ \\
\hline DP & 0.0027 & (41) & 0.0034 & 0.0037 & 0.0047 & 0.0024 & $(80)$ \\
\hline $\mathrm{TP}$ & 0.0030 & (31) & 0.0040 & 0.0046 & 0.0062 & 0.0033 & (53) \\
\hline $\mathrm{K}^{+}$ & 0.58 & (20) & 0.58 & 0.64 & 0.40 & 1.53 & (10) \\
\hline $\mathrm{Na}^{+}$ & 7.63 & (21) & 5.94 & 12.6 & 4.71 & 27.4 & (4) \\
\hline $\mathrm{Ca}^{2+}$ & 8.06 & (29) & 6.14 & 12.9 & 3.69 & 35.3 & (2) \\
\hline $\mathrm{Mg}^{2+}$ & 2.43 & (22) & 2.19 & 2.89 & 1.18 & 5.41 & (2) \\
\hline $\mathrm{Cl}^{-}$ & 7.45 & (8) & 7.96 & 6.00 & 7.02 & 4.80 & (2) \\
\hline $\mathrm{SO}_{4}{ }^{2-}$ & 7.33 & (14) & 7.96 & 6.50 & 7.30 & 5.94 & (4) \\
\hline $\mathrm{HCO}_{3}{ }^{-}$(meq $\left.\cdot \mathrm{L}^{-1}\right)$ & 0.57 & (37) & 0.33 & 1.12 & 0.12 & 3.20 & (1) \\
\hline $\mathrm{SiO}_{2}-\mathrm{Si}$ & 7.30 & (10) & 7.79 & 8.82 & 5.79 & 15.6 & (5) \\
\hline ion balance & 0.99 & - & 0.99 & 1.00 & 1.03 & 0.99 & - \\
\hline $\mathrm{Ta}\left({ }^{\circ} \mathrm{C}\right)$ & 20.0 & (43) & - & - & - & - & - \\
\hline $\operatorname{Tw}\left({ }^{\circ} \mathrm{C}\right)$ & 16.8 & (43) & - & - & - & - & - \\
\hline flow $\left(\mathrm{m}^{3} \cdot \mathrm{km}^{-2} \cdot \mathrm{s}^{-1}\right)$ & 0.0348 & (35) & - & - & - & - & - \\
\hline
\end{tabular}

* The yearly averages were calculated from the monthly data, and the sites were shown in Fig. 1. 
の $0.004 \sim 0.007 \mathrm{mg} \cdot \mathrm{L}^{-1}$ 前後であり, ばらつきも大きく 明瞭な傾向は認められなかった。

主要イオンの濃度は $\mathrm{N}, \mathrm{P}$ と比較して, ばらつきが非 常に小さく安定していた。 $\mathrm{K}^{+}, \mathrm{Cl}^{-}, \mathrm{SO}_{4}^{2-}$ は $\mathrm{TN}$ とほぼ 同様に変化したが, $\mathrm{Ca}^{2+}, \mathrm{Mg}^{2+}, \mathrm{HCO}_{3}{ }^{-}$は逆にR7 でや や低く，R5 にかけて徐々に上昇し，それ以降はほほ一 定で流下した。ただし, $\mathrm{Na}^{+}$と EC は流下過程でほとん ど変化しなかった。各定点のイオンバランスは 0.98〜 1.03 の間であった。結局, 主流域である R 流域の末端 $\mathrm{R} 0$ とその上流側約 $1 / 2$ の距離（量水堰から約 $130 \mathrm{~m}$ 上 流）内に配置した定点 $\mathrm{R} 1 \sim \mathrm{R} 4$ との間に，有意の濃度 差（P<0.01）がある水質項目はなく，この区間でそれ ぞれ収斂し安定していた。

次ぎに, 支流域 $\mathrm{L} （ \mathrm{~L} 1 \sim \mathrm{L} 4)$ について見ると, 最上 流の L4 は距離的に近い $\mathrm{R}$ 流域の R3, R4 と大差はなかっ たが, TP と $\mathrm{NH}_{4}-\mathrm{N}$ 以外はやや低濃度であった。しかし， 次の定点 L3 で水質は急変した。3.4で述べるように直 前で著しく水質・組成が異なる湧水 L5 が流入したため であった。ただし，L4 と L5 との濃度差が比較的小さかっ た $\mathrm{TN}, \mathrm{NO}_{3}-\mathrm{N}, \mathrm{TP}, \mathrm{Cl}, \mathrm{SO}_{4}{ }^{2-}$ は, $\mathrm{L} 1$ まで流下するま でにほほ L4の水質に戻った。

\section{2 基底流のイオン組成}

天然水を主要無機イオン組成によってアルカリ土類炭
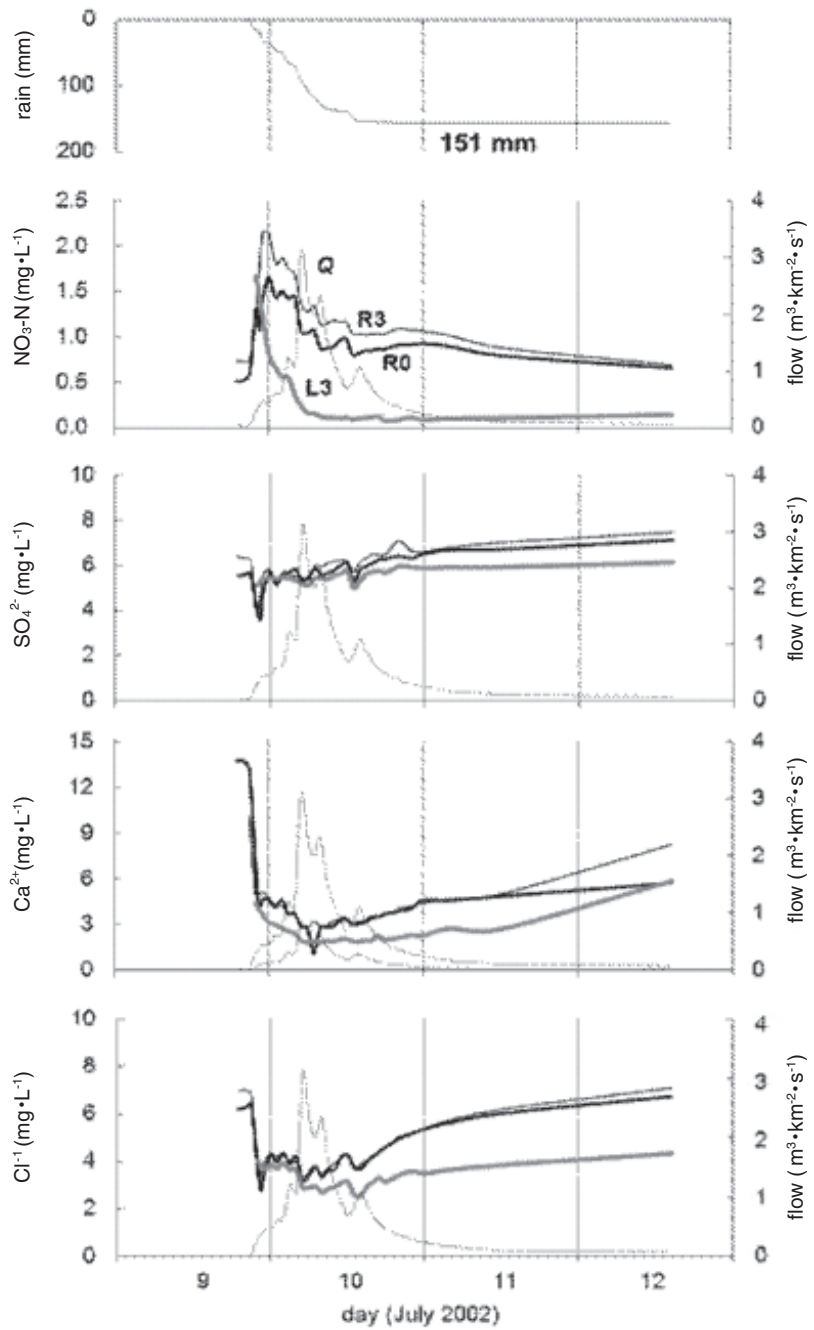

酸塩型 $\mathrm{I}$, アルカリ土類非炭酸塩型 II, アルカリ非炭酸 塩型 III, アルカリ炭酸塩型 $\mathrm{V}$ に分類するトリリニアダ イアグラム上に, 基底流平均水質をプロットした結果 をFig. 3 に示した。 R 流域についてみると, すべて II 型

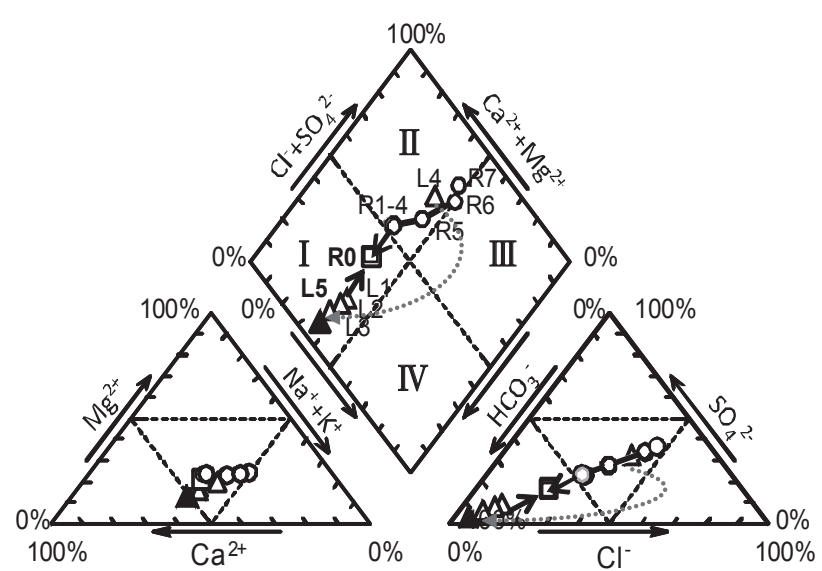

Fig. 3 Trilinear diagram of the average inorganic compositions of the base-flow in the sub-watershed-R and LW in AsEFW. $\bigcirc$ and $\triangle$ were sites on the streams in the sub-watershed-R and L, respectively. $\square$ was R0 just upstream of the weir of AsEFW, and $\mathbf{A}$ was L5. The data were the same as those used in Fig. 2.
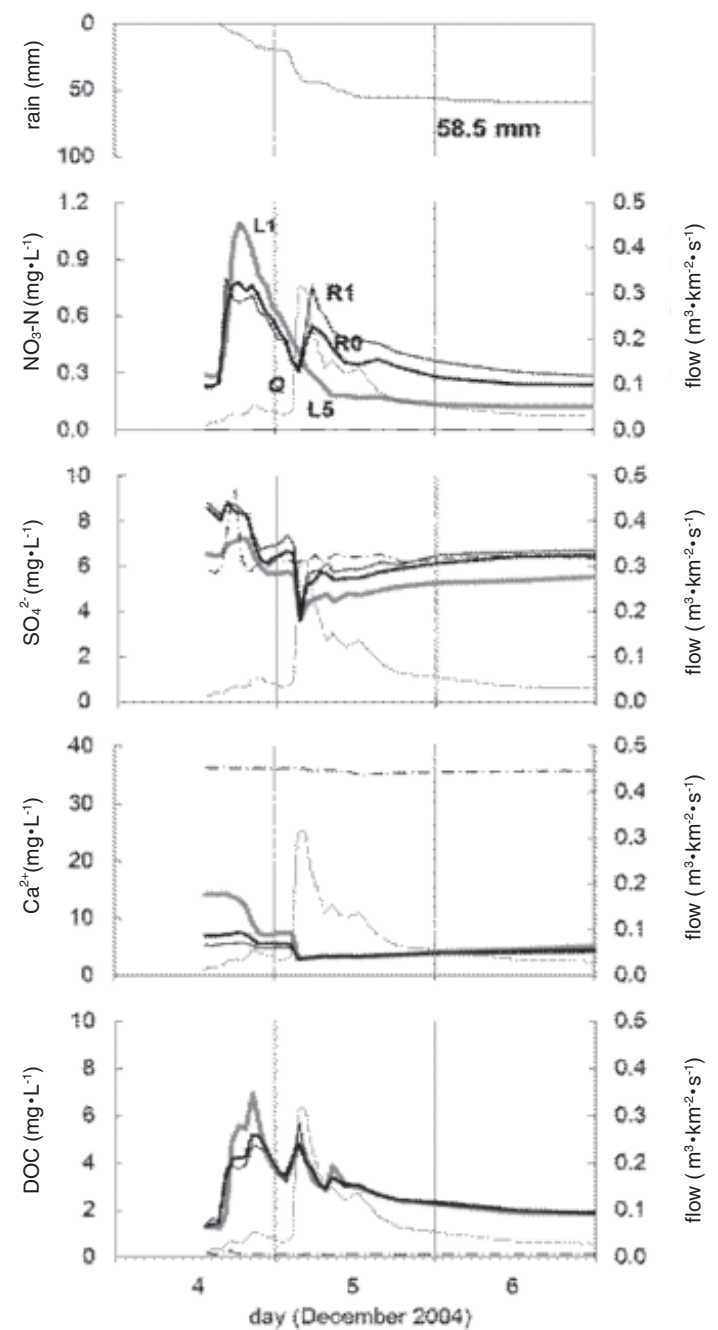

Fig. 4 Changes of concertrations during stormrunoff events measured at Site R0, R1, R3, L1, L3 and L5 in Aburahi-S Experimental Watershed. Flow rates $(\mathrm{Q})$ were maesured at the weir $(\mathrm{R} 0)$. 
に属したが，上流域（R7〜 R5）は开型との中間型で遷 移したのに対して，下流域（R4～R1）は I 型との中間 型でほぼ同じ位置に重なった。すなわち，イオン組成は R7 から R4 の間は変化したが，R4 から下流ではほぼ一 定值に収斂し安定していた。

L 流域について見ると，最上流の L4 は距離的には R3，R4 に近いが（Fig. 1)，イオン組成はR5 とR6に近 いII 型に属した。しかし， I 型に属する L5 が流入する L3のイオン組成は, L5に近い組成まで激変した。その後, L2 〜 L1 へ流下するにつれて L4 の組成に向かって変化 したが, その影響は最下流定点 L1でもまだ強く認めら れた。その結果, 流域末端 R0 のイオン組成は R1 と L1 との中間的な位置を占めた。

\section{3 洪水流出の水質変化}

$151 \mathrm{~mm}$ と $58.5 \mathrm{~mm}$ の降雨時に行った洪水流出水質精密 調査結果から主な定点の水質変動を Fig. 4 に示した。ま ず，両洪水流出に共通する特徵をみると，流量変化に伴 う濃度変化はピーク流出時より流出初期により強くあら われる傾向が認められた。この初期流出時の溶存性成分 の濃度変化は，物質によって次の 3 パターンに分かれた。

(1)ピークを形成した成分………….... $\mathrm{NO}_{3}-\mathrm{N}, \mathrm{DOC}, \mathrm{K}^{+}$

(2)小ピークまたは谷を形成した成分 $\cdots \mathrm{Cl}^{-}, \mathrm{SO}_{4}{ }^{2-}$

(3)急低下した成分……… $\mathrm{Na}^{+}, \mathrm{Ca}^{2+}, \mathrm{Mg}^{2+}, \mathrm{HCO}_{3}{ }^{-}, \mathrm{EC}$

一方, 流量のピーク時は(1)の成分のうち $\mathrm{NO}_{3}-\mathrm{N}$ は $\mathrm{R}$ 流域では第 2 のピークを形成したが，L 流域ではピーク は現れず低下し続けた。しかし, DOC と $\mathrm{K}^{+}$には両流域 とも第 2 ピークが認められた。(2), (3)に属する成分は多 かれ少なかれ谷になった。降雨後の流量回復時をみると, 降雨前の濃度より上昇する成分, 低下する成分, ほぼ回 復する成分があったが, 降雨によって一定ではなかった。

流域末端 R0 と R1 および約 $100 \mathrm{~m}$ 上流に配置した 定点 R3 との間で濃度と変動パターンを比較すると, $\mathrm{NO}_{3}-\mathrm{N}$ は濃度レベルが多少異なったが, 変動パターンに 大きな相違は認められなかった。主要イオンは濃度レべ ル, 変動パターンともこれらの定点間でほぼ同調して変 動した。

\section{4 湧水とその水質影響}

Table 1 をみると, L5 の主要イオンの標準偏差は, R0 と比較して明らかに小さく, 水質は非常に安定してい た。また，すべての陽イオンと $\mathrm{SiO}_{2}-\mathrm{Si}$ および $\mathrm{EC} は$, L5 の影響を受けていない R1 P L4より明らかに高濃度 であった。一方, 陰イオンでは $\mathrm{Cl}^{-}$と $\mathrm{SO}_{4}{ }^{2-}$ はむしろ低 く, イオンバランス (0.99) は $\mathrm{HCO}_{3}^{-}$でとれていた。な お, Fig. 2 でL5 が流入した後の L3〜 L1 定点の主要イ オンの標準偏差が流入前の L4 より明らかに大きくなる 物質があった。これはL5 の水質と湧出量がほぼ一定で あったのに対して，基底流とみなした流量が調査ごとに 異なったためにL5 の希釈率が毎回異なり, 両者の濃度 差が大きい物質ほど濃度変化が大きくあらわれたためで あると考えられた。Fig. 3 のトリリニアダイアグラムで は, L5 の影響を受けていない渓流定点（R1～7, L4） は II 型に属したが，L5 はアルカリ土類炭酸塩型 I に属 し，イオン組成も明らかに異なった。

洪水流出時の水質変化を Fig. 4 の $58.5 \mathrm{~mm}$ の降雨につ いて見ると, L5 はどの物質もほとんど濃度は変化せず, ほぼ一定で（理由は不明であるが, $\mathrm{SO}_{4}{ }^{2-}$ のみ流出初期
に一時的に上昇した), その他の定点と大いに異なって いた。このようにL5 は主要イオンの基底流濃度と組成 がその他の定点と大きく異なっており, かつ洪水流出時 も濃度・組成がほとんど変化しなかったことから，地下 水起源の湧水であると考えられた。

\section{5 植生組成と水質}

湧水 L5 の影響を受けない $\mathrm{R}$ 流域でも, 基底流水質は R7 から R1 まで流下する過程で多かれ少なかれ変化し た（Fig. 2)。AsEFW の下流側はヒノキ林であるが，上 流側には落葉広葉樹林が残されている $($ Fig. 1)。そこで, 植生の影響を検討するために, それぞれの定点の集水域 でヒノキ林の占める面積割合をヒノキ林率 $\gamma(\%)$ と定 義して, 基底流水質との関係を解析した。

$$
\gamma_{i}=\left(S_{C i} / S_{i}\right) \cdot 100
$$

ここで, $S_{i}$ と $S_{C i}$ はそれぞれ定点 $\mathrm{i} の$ 集水域の面積と その内部のヒノキ林の面積である。 $\mathrm{R}$ 流域では最上流の R7 で $\gamma$ は $0 \%$ ，最下流の R1で 43\%であった。

各定点の $\gamma$ と平均基底流水質との関係を Fig. 5 に示し た。 $\mathrm{NO}_{3}-\mathrm{N}$ については濃度と $\gamma$ との間に一定の関係は認 められず, R1 とR7 との間に有意差もなかった。図示 しなかったが $\mathrm{TN}, \mathrm{TP} て ゙ も$ 同様であった。なお, $\mathrm{Ca}^{2+}$ と $\mathrm{HCO}_{3}{ }^{-}$は上流域の $\mathrm{R} 7 \sim \mathrm{R} 6$ で低く, 下流域の R4 R1 で高濃度になり, その間の平均濃度の差は $\mathrm{p}<0.01$ で有 意であった。 $\mathrm{K}^{+}$と $\mathrm{SO}_{4}^{2-}$ は逆の傾向を示した。結局, 基 底流水質と植生の間に有意の関係は見出せなかった。

\section{4. 考察}

基底流水質調査によって AsEFW の主流域 R の谷頭 $\mathrm{R} 7$ から量水堰 $\mathrm{R} 0$ までの 8 定点の $\mathrm{TN}$ および $\mathrm{NO}_{3}-\mathrm{N}$ の 基底流濃度は, 一定（均質）ではなかったが（Fig. 2)， 有意差（p<0.01）はないことがわかった。各定点の濃 度のばらつきは主要イオンより明らかに大きく, 降水量 の季節変動 ${ }^{4,5,22)}$, 脱窒などの季節によって活性が変化 する土潩微生物 ${ }^{23 \sim 25)}$ などの影響を強く受けていると推
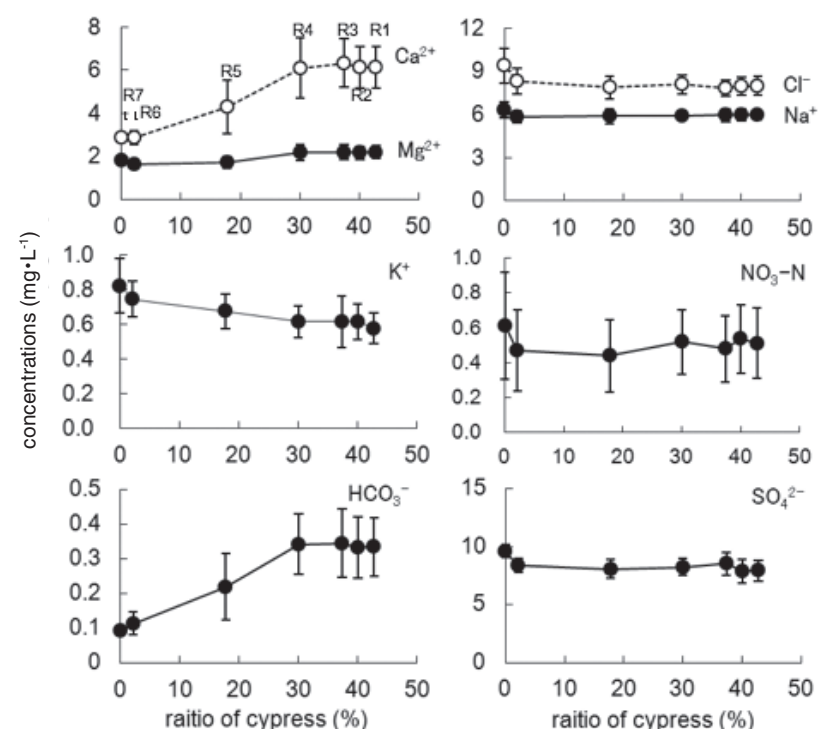

Fig. 5 Relationships between the water quality of baseflows and the ratio of the area covered by Japanese cypress to the total catchment area at each measuring site in the sub-watershed $\mathrm{R}$ within AsEFW. The unit of $\mathrm{HCO}_{3}^{-}$is meq $\mathrm{L}^{-1}$. 
察された。一方, TP は定量下限以下の低濃度でさらに ばらつきは大きかったが，やはり流下過程での平均濃度 の変化に有意差はなかった。

主要イオンでは $\mathrm{Ca}^{2+}, \mathrm{K}^{+}, \mathrm{SO}_{4}{ }^{2-}, \mathrm{HCO}_{3}{ }^{-}$の濃度は, 上 流域では一定の傾向を示し, R0 と R7 の間には有意差 が認められた。しかし, 下流域の R0 と R1〜R4 定点と の間にはすべての主要イオンについて有意差は認められ なかった。AsEFW は上流域が落葉広葉樹, 下流域がヒ ノキ人工林で, 流下過程で植生が徐々に変化する。そこ で, ヒノキ林率を定義して $\mathrm{R}$ 流域について基底流出水質 との相関を検討したが, 有意の相関は認められなかった。 これらの物質は岩石の風化と関係の梁い成分 ${ }^{26)}$ であるの で主要イオン組成の変化を検討したところ， R 流域の定 点はすべてアルカリ土類非炭酸塩型に属したが，流下す るに従ってアルカリ非炭酸塩型との境界型からアルカリ 土類炭酸塩型との境界型へ移行したことから（Fig. 3), 上流域と下流域で岩石組成または風化速度に相違があ り，それが基底流水質に反映したためであると推察され た。ちなみに, $\mathrm{HCO}_{3}$ 外外のすべての物質は最上流の定 点 R7 では, R6 または R5 よりわずかに高濃度であった (Fig. 2, 5)。これは日照や大気の影響をより強く受ける 斜面最上部では, 蒸発散による乾燥すなわち土壤水の濃 縮がより強く働くためと推察された。

洪水流出水質精密調査では, $\mathrm{NO}_{3}-\mathrm{N}$ には R0 と R1, $\mathrm{R} 0$ とR3 との間に濃度レベルと変動パターンに大きな 相違は認められず，ほぼ同調して変動した。これらの定 点では初期流出時と流量ピーク時に濃度が上昇する 2 山 の変動パターンを示し, かつ降雨が終わって流量がほぼ 回復しても降雨直前の濃度には戻らずやや高く維持され た。一方, L1, L3 では初期流出時は同様に濃度ピーク を形成したが, それ以降は流量ピークに関係なく濃度 は低下し, 流量回復時には降雨直前より低下した。初 期流出ピークについては R, L 雨流域で見られたこと, $\mathrm{NO}_{3}-\mathrm{N}$ は溶存性成分であることから, 河川の中〜下流で
みられるような河床堆積物の掃流の寄与は小さく, 河床 に落下した $\mathrm{NO}_{3}$ - $\mathrm{N}$ の初期濃度が高い林外雨 $\left.4,5,8,22\right) \cdot$ 林 内雨 ${ }^{8)}$ の直接流出に起因すると推察された。流量のピー ク時から流量低減期は, 両流域で異なった挙動を示した が, 土畩水の $\mathrm{NO}_{3}-\mathrm{N}$ 濃度, 斜面下部での帯水帯の存在 などが渓流の窒素流出に影響することが指摘されてお $\eta^{24)}$ ，これらの条件が $\mathrm{R}$ 流域と L 流域で異なることに 起因すると推察されたが, 引き続き検討する必要がある。 主要無機イオン濃度は流量の変化に伴ってそれぞれ 異なったパターンで大きく変化したが, R0 とR1, R0 とR3との間で同様にほぼ同調して変動した。また, $58.5 \mathrm{~mm}$ の降雨時について流下過程に伴うイオン組成の 変化を検討したFig. 6 を見ると, R0, R1, L4 では大き くは変化しなかったことから, 洪水流出時の濃度変動は これらのイオン濃度が低い降雨 ${ }^{5,22)}$ による希釈が主因で あると推察された。

L 流域の L3 の直前に湧出していた L5 の水質は, そ の影響を受けていない渓流定点（L4, R7〜R1）の基底 流濃度と明らかに異なっており（Fig. 2), 主要イオン組 成もアルカリ土類炭酸塩型でやはり明らかに異なってい た $($ Fig. 3)。さらに, 洪水流出時も渓流定点とは大きく 異なり, 濃度 (Fig. 4) も, イオン組成 (Fig. 6) も降雨 の影響をほとんど受けず, 湧出水量も目視ではあったが ほとんど変化しなかった。これらの結果から L5 は地下 水起源の湧水であると考えられた。ちなみに, L5 が直 前で流入する L3 を見ると, 洪水流出初期は湧水 L5 の 組成に近かったが, 渓流の流量が増加し始めると L4 の 方向に大きく移動し, 流量ピーク後再びL5のイオン組 成の方向に戻っていった。その際, 陽イオンの組成変化 は小さく, 除イオンの組成が大きく変化した。陰イオン 組成は $\mathrm{HCO}_{3}{ }^{-}$が主として変化し, 主に $\mathrm{Cl}^{-}$がそれを補償 するように変化した。

大流域の森林に大小の湧水が存在することは特別なこ とではないので, 広域河川法による水収支や物質収支は

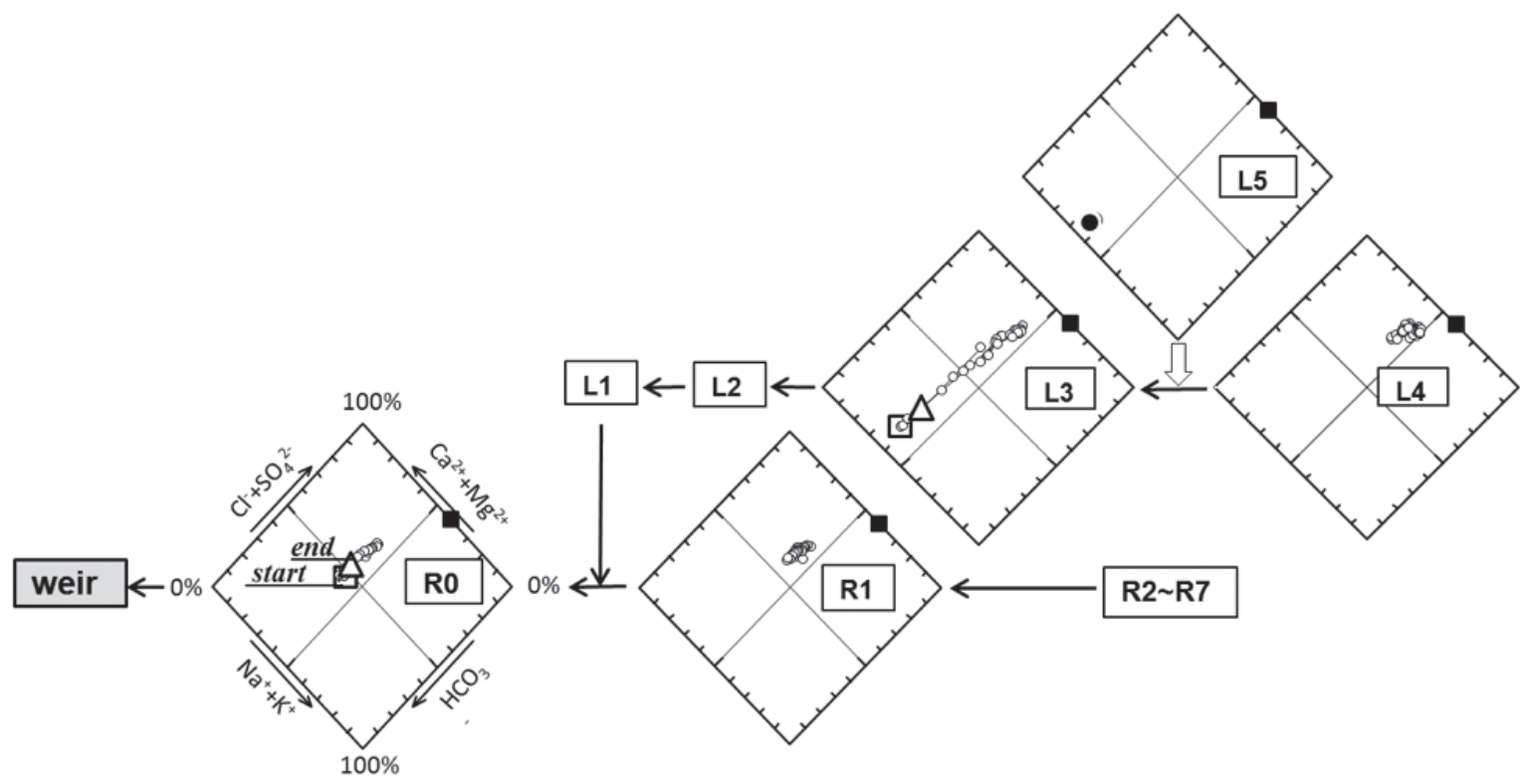

Fig. 6 Key diagrams of the changes in the compositions of the major inorganic ions measured at the sites of R0, R1, L3, L4 and L5 during the stormrunoff cased by the rainfall of $58.5 \mathrm{~mm}$ (4-6, December 2004). $\bigcirc$; compositions of the stream measured at R0, R1, L3 and L4, and $\square$ start: beginning of measuring before the rainfall, $\triangle$ end: end of measuring after the rainfall. $\bullet$; the compositions of the spring measured at L5. $\mathbf{\square}$; the composition of the deposited rainfall. 
それらを含めた解析結果であると解釈される。しかし， 小流域では流量が小さいことから，涵養域や起源が不明 な湧水の存否はその規模と水質によっては濃度や比流出 量に大きく影響する。すなわち，小流域法で得られた比 流出量の代表性を担保するためには, 湧水の有無とその 影響の確認は必須の要件であるはずである。ところがこ れまで小流域法による森林の物質収支や原単位に関する 研究で湧水の有無に言及された事例は見当たらない。

AsEFW では湧水 L5 の存在が確認されたので, まず $\mathrm{R} 0$ の基底流水質に対する湧水の影響度 $\beta$ を以下のよう に定義して，物質ごとに検討した。実験小流域が均質 で L5 が存在しなければ R 流域と L 流域の末端定点 R1, L1 および合流直後の R0 の水質と比流量はすべて等し く, かつ L5 の湧出水量は R0 の流量と比較して無視で きる程度であると仮定すると，L5 が存在しなかった場 合の R0 における流出量 L は次式で与えられる。

$$
L=S Q_{\mathrm{R} 0} C_{\mathrm{R} 1}
$$

ここで, $S$ は流域面積, $Q_{\mathrm{R} 0}, C_{\mathrm{R} 1}$ はそれぞれ R0 にお ける実測比基底流量と R1 における実測基底流水質であ る。次ぎに, R0での実測流出量と, 影響を受けていな いと仮定した流出量の差 $\Delta L$ は次式で与えられる。

$\Delta L=S Q_{\mathrm{R} 0}\left(C_{\mathrm{R} 0}-C_{\mathrm{R} 1}\right)$

ここで， $C_{\mathrm{R} 0}$ は R0 における実測基底流水質である。

$\beta$ は (2), (3)式から次式で定義する。

$\beta=\Delta L / L=\left(C_{\mathrm{R} 0}-C_{\mathrm{R} 1}\right) / C_{\mathrm{R} 1}$

Table 1 のデータを用いて主な物質について計算した $\beta$ を以下に示した。

$\mathrm{TP}<\mathrm{TN}<\mathrm{SO}_{4}^{2-}<\mathrm{Cl}^{-}<\mathrm{K}^{+}<\mathrm{EC}<\mathrm{Na}^{+}<\mathrm{Ca}^{2+}$

$\beta=-0.25-0.12-0.08-0.06+0.00+0.20+0.29+0.31$

このように $\beta$ は物質によって $-0.25 \sim+0.31$ の広い範囲 の值を与えた。TN は L5 の方が R1 より明らかに低濃度 で， $\beta$ は $-12 \%$ と計算され, TP も定量下限以下の濃度で はあったが，-25\%と計算された。L5 はこれらの物質に

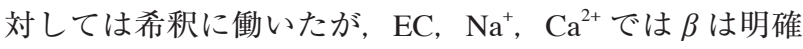
に正の值になり，濃度を高めるように作用した。このよ うに湧水の基底流水質に対する影響度は, 両者の水質の 相互関係で決まるために，基本的に物質毎に異なる。そ のため目的物質ごとに確認する必要がある。

一方, 洪水流出時は渓流定点 R0 では流量は急増し濃 度も急変する。しかし, 湧水 L5 では湧出水量も水質も ほとんど变化しなかった (Fig. 4, 6)。従って, 洪水流出 時に濃度が上昇する $\mathrm{TN}, \mathrm{TP}$ などの成分は渓流からの流 出量が著しく増大するので6,7,9 11)，R0 で測定した洪水 流出量に対するL5の影響は小さいと推察された。さら に，これらの成分の年比流出量の過半は洪水流出が占め るので，年比流量に対する L5 の影響は無視し得る程度 と考えられる。主要イオンについてみると, 洪水流出初 期と終期の流量が少ない時期は， R0 のイオン組成に L5 の影響が認められたが，流量が増加すると R1 とほぼ同 じ位置で変化した (Fig. 6)。洪水流出時の物質流出は流 量増加期が大部分を占めることを考え合わせると，主要 イオンについても洪水流出量に対する L5 の影響は限定 的であると考えられた。

結局，湧水の起源は実験小流域外の林地に及ぶことを 前提にすると, その存在は比流出量の過大評価に繋がる が，その影響は， $\beta$ が大きく比流出量に占める基底流
出量の割合が大きい物質ほど大きくなると考えられる。 AsEFW では TN, TPについては $\beta$ がいずれも負で, 比 流出量に占める基底流出量の占める割合はそれぞれ 28 , $17 \%{ }^{7)}$ に過ぎなかったので, 影響は小さいと推察された。 しかし， $\beta$ が大きく, 基底流出量の割合が大きい溶存物 質 ${ }^{6}$ では, 比流出量に与える影響は無視できない。

\section{5. 総括}

森林小流域で測定した流出渓流の濃度と比流出量は, 小流域内部で収斂し安定していなければその森林を代表 するパラメーターとしては評価できないが，それを小流 域内部に多くの量水堰を設置して直接検証することは実 際には困難である。そこで, さきにL $(\mathrm{R})$ 式法 ${ }^{6,7)}$ を適 用して流出量を基底流出量と洪水流出量に分けて推定 した油日岳 S 森林実験小流域 (AsEFW， 3.34 ha）の比 流出量 $\left(\mathrm{TN}: 9.95 \mathrm{~kg} \cdot \mathrm{ha}^{-1} \cdot \mathrm{y}^{-1}, \mathrm{TP}: 0.168 \mathrm{~kg} \cdot \mathrm{ha}^{-1} \cdot \mathrm{y}^{-1}\right)^{7)}$ について, 内部の渓流に $20 \sim 40 \mathrm{~m}$ 間隔で主流域 $\mathrm{R} に$ 8 定点（量水堰直上 $\mathrm{R} 0$ から上流に $\mathrm{R} 1 \sim \mathrm{R} 7$ ), 支流の $\mathrm{L}$ 流域に 5 定点（L1 〜 L4, 湧水 L5）を設定し, 基底流 水質調查 (1 回/月, 1 年間) と洪水流出水質精密調査 （58.5，151 mm）を行い, 比流出量の代表性を代替的に 検証した。また, 湧水と植生の影響についても検討した。

1）基底流の年平均水質は, $\mathrm{TN}, \mathrm{TP}$, 主要イオンの いずれについてもこれらの定点で均質ではなかったが, 少なくとも最下流の R0 と下流側約 $1 / 2$ の距離（R0 から 約 $130 \mathrm{~m}$ 上流）内の定点 $\mathrm{R} 1 \sim \mathrm{R} 4$ との間には有意差は なかった。洪水流出については, $\mathrm{NO}_{3}-\mathrm{N}$, 主要イオンと もに R0 と R1, R0 と R3 との間に濃度レベルと変動パ ターンに大きな相違は認められず, ほぼ同調して変動し た。これらの結果から TN, TP, 主要イオンの濃度と比 流出量は, AsEFW の内部で収斂し安定していると判定 した。

2）湧水 L5 が渓流水質に与える影響は, 洪水流出 水質については小さかったが, 基底流水質に対しては $\mathrm{TN}, \mathrm{TP}, \mathrm{SO}_{4}{ }^{2-}, \mathrm{Cl}^{-}, \mathrm{K}^{+}$については無視し得る程度であっ

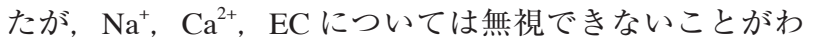
かった。また, 湧水による比流出量の過大評価の程度は, 基底流水質に対する影響が小さく，洪水流出量が主であ る $\mathrm{TN}, \mathrm{TP}$ では小さいが, 基底流水質に対する影響が大 きく，基底流出量が主である溶存物質では無視し得ない と推察された。

3）上流域に残置二次林が存在する $\mathrm{R}$ 流域について, ヒノキ林の面積率の増加と基底流の $\mathrm{TN}, \mathrm{TP}$, 主要イオ ン濃度との関係を検討したが, いずれについても有意の 相関関係は認められなかった。

\section{謝 辞}

本研究は滋賀県琵琶湖研究所 (現琵琶湖 - 環境科学研 究センター）の集水域研究プロジェクト（1995～2004 年度）の一環として行った。油日岳 $\mathrm{S}$ 森林実験流域で の量水堰設置および調査に協力していただいた油日・上 野生産森林組合および油日区民に感謝します。

（原稿受付 2009 年 8 月 31 日) （原稿受理 2010 年 7 月 2 日) 


\section{参 考 文 献}

1 ) Likens, G. E. and Bormann, F. H. (1988) Biogeochemistry of a Forested Ecosystem, 159pp., Springer-Verlag, New York.

2 ) Swank, W. T. and Crossley, D. A. (1988) Introduction and site description, in "Forest Hydrology and Ecology at Coweeta" (Ed. Swank, W. T. and Crossley, D. A.), pp.3-31, Springer-Verlag, New York.

3 ）國松孝男, 村岡浩爾編著（1989）「河川污濁とモデル解析」, 266pp., 技報堂出版, 東京.

4 ）國松孝男, 須戸 幹 (1993) 山地河川の窒素・リン・CODの濃度 とその変動特性 - 森林 (油日岳試験流域) からの污濁負荷流出機 構 I, 農業土木学会論文集, 61 (4), 35-44.

5 ) Kunimatsu,T., Hamabata, E., Sudo, M. and Hida, Y. (2001) Comparison of nutrient budgets between three forested mountain watersheds on granite bedrock, Water Science \& Technology, 44 (7), 129-140.

6 ）國松孝男, 須戸幹 (1997) 林地からの污濁負荷とその評価, 水 環境学会誌, 20, 810-815.

7 ) Kunimatsu, T., Otomori, T., Osaka, K., Hamabata, E. and Komai, Y. (2006) Evaluation of nutrient loads from a mountain forest including storm runoff loads, Water Science \& Technology, 53 (2) , 79-92.

8 ) 岩坪五郎 (1989) 物質の動きと環境要因,「森林生態学」(堤利夫 編), pp.124-148, 朝倉書店, 東京.

9 ）梅本諭, 駒井幸雄, 井上隆信（1999）山林小水域における栄養 塩類の濃度変動と流出特性, 国立環境研究所報告「水環境におけ る流出特性に関する研究」, R-144, 101-113.

10）篠宮佳樹，山田毅，鳥居厚志 (2007) 四万十川源流部の森林流 域における降雨イベント時の溪流水質変動と L-Q 法への適合度, 森林立地, 49, 133-144.

11) Ide, J., Nagafuchi, O., Chiwa, M., Kume, A., Otsuki, K. and Ogawa, S. (2007) Effects of discharge level on the load of dissolved and particulate components of stream nitrogen and phosphorus from a small afforested watershed of Japanese cypress (chamaecyparis obtuse), $J$. Forest Research, 12, 45-56.

12）勝山正則, 大手信人, 内田太郎, 浅野友子, 木本秋津 (2000) 降 雨流出過程の相違が溪流水質形成機構に与える影響, 水文・水資
源学会誌, 13, 227-239.

13) Uchida, T., Asano, Y., Onda, Y. and Miyata, S. (2005) Are headwaters just the sum of hill slopes?, Hydrol. Process., 19, 32513261.

14）小川滋 (1988) 山地森林地帯の流出に与える影響とその評価従来の研究成果を中心にして, 農業土木学会誌, 56, 1101-1107.

15) Shaman, J., Stieglitz, M. and Burns, D. (2004) Are big basins just the sum of small catchments?, Hydrol. Process., 18, 3195-3206.

16）塚本良則著 (1998)「森林·水·土の保全」, pp.12-15, 朝倉書店, 東京.

17）環境庁水質保全局（2000)「湖沼水質対策マニュアル」, 36pp.

18）木村園子ドロテア, 岡崎正規, 波多野隆介（2006）広域におけ る窒素循環 - 評価の現状と今後の展望, 日本土壤肥学雑誌, 77 , 351-359.

19）兼松四郎（1975）土地分類図（表層地質図）滋賀県, 国土庁土 地局.

20）日本規格協会編（1998）JIS ハンドブック 53 環境測定 II（水質） K 0102 工場排水試験方法, 328pp., (財)日本規格協会, 東京.

21）厚生省生活局水道環境部監修（1993）上水試験方法 1993年版, $795 \mathrm{pp}$, (社)日本水道協会, 東京.

22) Kunimatsu, T., Nakazawa, K and Hartmann, J. (2008) Method of evaluating nutrient loads through the atmosphere onto lakes, Desalination, 214, 111-119.

23) Ohte, N., Mitchell, M. J., Shibata, H., Tokuchi, N., Toda, H. and Iwatsubo, G. (2001) Comparative evaluation on nitrogen saturation of forest catchments in Japan and northern United States, Water Air and Soil Pollution, 130, 649-654.

24) Osaka, K., Ohte, N., Koba, K., Katsuyama, M. and Nakajima, T. (2006) Hydrorogic controls on nitrous oxide production and consumption in a forested head-water catchment in central Japan, $J$. Geoph. Res., 111:G01013, doi: 10.1029/2005 JG000026.

25) Mitchell, M. J., Discoll, C. T., Murdoch, P., Likens, G. E., Kahol, J. S. and Pardo, L. (1996) Climatic control of nitrate loss from forested watersheds in the northeast United States, Environ. Sci. Tech., 30, 26092612.

26) Drever, J. I. (1997) The Geochemistry of Natural Waters: surface and groundwater environments (3rd ed.), 436pp., Prentice-Hall International, New Jersey. 